\title{
Globe luxation, complex eyelid laceration and lost medial rectus: extreme complication of ocular trauma
}

\author{
Nripen Gaur, Somya Kumari, Brijesh Takkar, Pradeep Sharma
}

Ophthalmology, Dr Rajendra Prasad Centre for Ophthalmic Sciences, AllMS, New Delhi, India

\section{Correspondence to} Professor Pradeep Sharma; drpsharma57@yahoo.com

Accepted 6 October 2019

\section{DESCRIPTION}

A 42-year-old man presented to our emergency services 2 days following blunt trauma caused by an iron rod during an alleged assault. The patient was conscious, alert and oriented to time, place and person. On general examination vital signs were found to be normal. On ocular examination a full thickness lid laceration involving lid margin of left upper lid with anterior luxation of eye ball was noted (figure 1A). The left eye was in gross exodeviation. There was no perception of light in the left eye, while the pupil was fixed and dilated. No corneal or scleral disintegrity was noted as the anterior chamber was well formed and intraocular pressure appeared normal as on palpation through the lower eye lid. No obvious anomaly was apparent in the right eye.

An urgent CT scan of head and orbit was done, which revealed complete transection of optic nerve along with disinsertion of left medial rectus from its insertion (figure 1B,C). No orbital fractures were noted. The patient was explained about the nil visual prognosis and a possible need for enucleation in the event of unsuccessful globe positioning
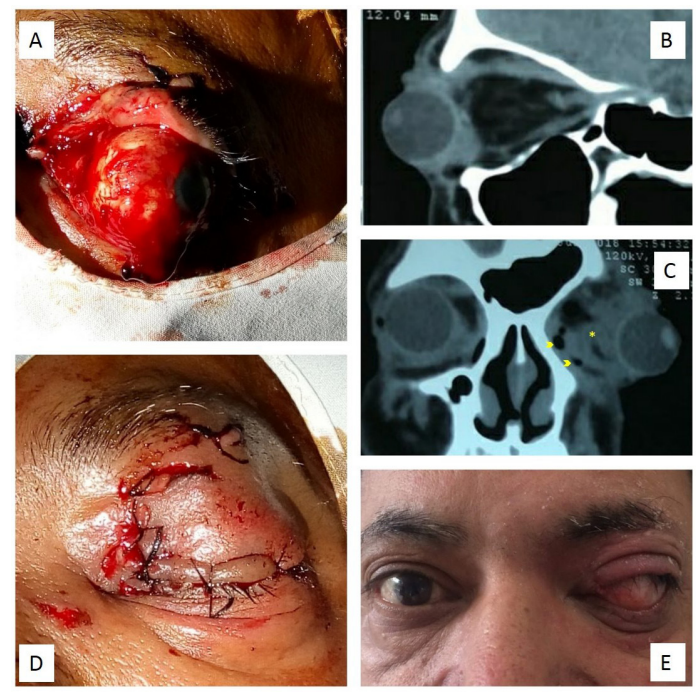

Figure 1 (A) Clinical photograph showing anterior luxation of the globe $(B, C)$ showing $C T$ images in sagittal and coronal section showing optic nerve transection (B). (C) Coronal section showing multiple foci of intraorbital air (arrows) along with the presence of disinserted medial rectus which can be seen retracted into the orbit (asterisk). (D) Immediate postoperative photograph. (E) Clinical photograph taken at 3-month follow-up showing marked exotropia and exophthalmos secondary to medial rectus disinsertion. due to delayed presentation. However, against our expectations, globe repositioning procedure with lid laceration repair was performed with relative ease under general anaesthesia (figure 1D). The globe was explored for wounds, but no scleral disintegrity was found. The medial rectus muscle was explored, but could not be identified. The medial rectus was disinserted from its insertion as a result of the force of trauma, as evidenced by a lack of residual muscle stump at the insertion site. No orbital fat prolapse was noted. The other extraocular muscles were explored and were found to be normally inserted. The globe was repositioned into the orbit by retracting the eyelids away from the globe using Desmarre lid retractor followed by gentle posterior pressure on the globe. The eyelids were opposed by a temporary suture tarsorrhaphy which was done using 4-0 silk suture. The Patient was given a postoperative antibiotic prophylaxis in form of oral ciprofloxacin. At 3-month follow-up, the globe was in its place with nil perception of light, however, a large angle exotropia was present due to the unopposed action of lateral rectus (figure 1E).

Anterior luxation of globe is a rare manifestation of ocular trauma. ${ }^{1}$ It can occur with or without avulsion of the optic nerve. Extreme rotation and forward displacement of the globe can cause shearing of the optic nerve fibres in cases of non-penetrating injuries. Lamina cribrosa is the most common site for avulsion of the optic nerve. ${ }^{2}$ Absence of supportive connective tissue septa make the axons vulnerable to damage at this location. Anterior luxation is followed by contraction of orbicularis oculi which causes further anterior displacement of globe, which can set up a vicious cycle increasing the globe luxation. Late presentation following globe luxation can lead to failure of manual globe repositioning necessitating eye lid procedures like canthotomy or cantholysis, and rarely enucleation. Enucleation is resorted only when either the integrity of the globe cannot be restored or globe repositioning is not possible with setting in of anterior ischaemia. In the current case, presence of the eye lid laceration made globe repositioning relatively easier and despite delayed presentation, complications of ischaemia were avoided.

Extraocular muscles may be affected as well, depending on the degree of trauma. The medial rectus is most commonly affected, followed by the inferior rectus, the superior rectus and the obliques in the decreasing order of frequency. Preservation of the globe can reduce psychological trauma to the patient. ${ }^{3}$ Despite best efforts, medial rectus could not be identified in our case at the time of 
globe repositioning, and subsequent cosmetic rehabilitation was planned for correction of the squint. A lost or torn muscle may be encountered in instances of trauma, strabismus surgery, inadvertent myectomies, during retinal reattachment surgery, or as a complication of orbital or paranasal sinus surgery. A lost muscle is characterised by the absence of any attachment of the muscle tendon or capsule to the sclera; whereas a torn or snapped muscle as one in which the muscle belly has ruptured across its width, posterior to the muscle insertion, while the insertion to the globe remains intact. In cases of lost medial rectus muscle, extraocular muscle (EOM) transposition procedures like vertical recti transposition and lateral recti transposition procedure to the medial rectus have proven to be of great benefit. Globe-tethering procedures can also be used correct strabismus resulting from such cases. In cases of torn muscles, both stump ends must be explored and reattached using absorbable sutures. CT scan or an MRI can provide important information regarding the diagnosis in case of a patient with suspected EOM injury. High resolution CT scans are gold standard in cases where orbital

\section{Learning points}

Rare combinations of traumatic events can make management difficult, necessitating subsequent rehabilitative procedures.

- Presence of eye lid laceration was helpful in our case, easing the globe repositioning. fracture is suspected. The MRI provides better understanding of the structural integrity of the muscle and soft tissues.

It is very important to confirm the status of tetanus toxoid prophylaxis. In this case, the patient had already received the tetanus toxoid prophylaxis prior to referral to our centre. The patient was counselled regarding monocular precautions and was advised polycarbonate plastic protection glass after surgery to prevent any inadvertent trauma to the healthy eye. He was also counselled for lifestyle measures and choice of occupation to prevent fellow eye trauma.

Contributors NG, SK and BT contributed to diagnosis, workup, writing the manuscript and performing critical revision. PS is the overall responsible for the presentation, contributed to diagnosis and performed critical revision of the manuscript.

Funding The authors have not declared a specific grant for this research from any funding agency in the public, commercial or not-for-profit sectors.

Competing interests None declared.

Patient consent for publication Obtained.

Provenance and peer review Not commissioned; externally peer reviewed.

\section{REFERENCES}

1 Amaral MBF, Carvalho MF, Ferreira $A B$, et al. Traumatic globe luxation associated with orbital fracture in a child: a case report and literature review. J Maxillofac Oral Surg 2015; 14:323-30

2 Tok L, Tok OY, Argun TC, et al. Bilateral traumatic globe luxation with optic nerve transection. Case Rep Ophthalmol 2014;5:429-34.

3 Bajaj MS, Kedar S, Sethi A, et al. Traumatic globe luxation with optic nerve transection. Orbit 2000;19:165-70.

Copyright 2019 BMJ Publishing Group. All rights reserved. For permission to reuse any of this content visit

https://www.bmj.com/company/products-services/rights-and-licensing/permissions/

BMJ Case Report Fellows may re-use this article for personal use and teaching without any further permission.

Become a Fellow of BMJ Case Reports today and you can:

- Submit as many cases as you like

- Enjoy fast sympathetic peer review and rapid publication of accepted articles

- Access all the published articles

Re-use any of the published material for personal use and teaching without further permission

Customer Service

If you have any further queries about your subscription, please contact our customer services team on +44 (0) 2071111105 or via email at support@bmj.com.

Visit casereports.bmj.com for more articles like this and to become a Fellow 